\title{
Review
}

\section{Kantian courage: Advancing the enlightenment in contemporary political theory}

\author{
Nicholas Tampio \\ Fordham University Press, New York, 2012, xii+255pp., ISBN: 978-0823245017 \\ Contemporary Political Theory (2015) 14, e9-e13. doi:10.1057/cpt.2014.57; \\ published online 23 December 2014
}

Tampio sums up the aim of his book by asking: 'Is it possible to envision a new Left, or a new Enlightenment, that somehow combines all of the different post-Kantian traditions into, say, a poststructuralist political liberalism?' (p. 108). These traditions are represented primarily by John Rawls's political liberalism and Gilles Deleuze's poststructuralist philosophy, but Tampio adds to the conversation reflections from committed Kantians such as Alan Wood and from Muslim thinker Tariq Ramadan. The objective in engaging this array of thinkers is to construct a path for political theorists committed to Enlightenment values of freedom, equality and pluralism to rework them so as to constitute alliances with greatly diverging perspectives across differences in race, gender and (particularly in a post-9/11 world) religion never considered by Kant and his contemporaries. For Tampio, this demands a kind of courage that Kant himself articulates, albeit inconsistently: not the courage to follow resolutely the commands of the moral law, but the courage to hold to one's convictions to think critically and creatively (p. 23), to invent new moral principles.

Kantian Courage can be usefully compared with another recent reassertion of Enlightenment values, Bronner's (2004) Reclaiming the Enlightenment. Bronner sees progressive Enlightenment liberalism sunk in a malaise because of relentless attacks from positions ranging from counter-Enlightenment conservatism to authoritarian Marxism and from 'half-hearted' liberalism to 'postmodern' relativism. His defence turns, first, on accusing these critics of prioritizing metaphysics over proper political history, of aestheticizing politics, and of failing to keep clear the distinctions between Enlightenment liberalism and counter-Enlightenment totalitarianism and fascism; and, second, on excusing the racism, sexism and other failings of historical Enlightenment thinkers and liberal states as mere products of their time. Bronner's message is simple: do not forget that liberalism is better than fascism, and shoot any messengers with something else to say.

In contrast, Tampio holds that dogmatic attachment to the Enlightenment is a significant part of the problem. We must recognize that the Holocaust and other 
recent atrocities 'display a colossal failing of the common sense that Kant appealed to in his practical philosophy' (p. 75) and that 'certain aspects of the Enlightenment ... clearly need to be jettisoned or refashioned' (p. 2). Moreover, we must understand that the Enlightenment, born out of devastating religious wars, produced a settlement based on secularized politics, but one that presumed a shared Christian biblical heritage, using an originally Christian concept (the secular) to establish a separation of religion and politics, and has since suffered a global reaction against it (pp. 4-7). It is therefore incumbent upon political theorists committed to Enlightenment progressivism 'to expand their mental maps of the constituencies discussing a common future of religious peace or strife' (p. 5). Finally, we must follow Foucault in differentiating Kantian universalist morality as a now problematic historical relic from the still 'living project' (p. 13) of criticism and the search for positive change. In this sense, it is 'an ethos rather than a doctrine' (p. 17) that connects today's progressive political thought to the Enlightenment. Despite many differences, Rawls and Deleuze share this ethos, refusing either slavishly to follow or simply to reject Kant's philosophy and instead reworking Kantian principles to make them suitable for today.

The core of the book formulates the problems a renewed Kantianism must overcome and presents Rawls's and Deleuze's strategies in relation to them. The key problems are that practical reason must be separated from Kant's two-world metaphysics and naturalized in accordance with philosophical and scientific (that is, Darwinian) understandings of affect, passion, imagination and the visceral conditions of thought; that the common sense Kant affirms must be subjected to critical scrutiny, challenging today's doxa with the para-doxical ${ }^{1}$ and that any new theory must confront what Rawls calls the 'fact of reasonable pluralism', in relation to which Kant's pluralism is decidedly narrow. Rawls and Deleuze each respond to these problems with a form of constructivism. Constructivism accords with the principle of Kant's 'Copernican Revolution', whereby humans make rather than discover their rules for knowledge and morality, and it further 'historicizes, naturalizes, and politicizes Kant's metaethics' (p. 124), reflecting the Kantian courage Tampio affirms. Rawls and Deleuze share in the constructivist activities of inventing conceptual personae (Rawls's rational agent and Deleuze's BwO (Body without Organs)), placing them on a plane of thought (Rawls's original position and Deleuze's plane of immanence), and from there developing theories that set 'the construction of concepts and principles in motion by thinking about the actions of the conceptual persona on the terrain of thought' (p. 136) and evaluating these theories with immanent principles (Rawls's reflective equilibrium and Deleuze's Nietzschean ethics of good and bad). Proceeding in these ways, 'Rawls ... participates in the moderate branch of the Enlightenment that seeks common cause with citizens of faith, and Deleuze extends the tradition of radical Enlightenment that advances the Spinozist project of demystifying religion' (p. 114). ${ }^{2}$ While Rawls, using a narrower but well-established political philosophy vocabulary, 'has a greater chance of widespread appeal', Deleuze 'stretches the range of the politically imaginable' (p. 135). 
But Rawls's approach can aid Deleuze's in much the same way as the moderate Enlightenment supported its more radical brother when it 'translated the ideas of the radical Enlightenment into a more comprehensible and acceptable language for the authorities and the general populace' (p. 155).

The final chapter considers how a renewed Enlightenment can 'generate new concepts and principles to facilitate beneficial political-religious alliances' (p. 160), particularly with regard to Islam. This involves reworking Kant's idea of ethical community, which assumes a common Christian core to the diverse faiths it brings together, so as 'to renovate the Enlightenment's commitment to interfaith respect and cooperation' (p. 167). Rawls presents the idea of 'overlapping consensus' as a continual work in progress that welcomes diverse constituencies that measure up to the standards of a decent people, while Deleuze offers the concept of the 'assemblage' as a way of conceiving 'political coalitions without a center' (p. 177). Ramadan enters the discussion through his 'call for Muslims to reread their sources to enact an intellectual revolution along the lines of Kant's Copernican revolution' (p. 178). His 'space of testimony' offers a way for Muslims to negotiate a path that pays heed to both religious commitment and the demands of Western democratic citizenship, displaying a Kantian courage that makes Ramadan a possible ally to Enlightenment liberals across this religious divide.

Bringing Deleuze more centre stage in contemporary democratic political theory is an important motivation for Tampio, and one he has also expressed elsewhere (see Tampio, 2014). To this end, putting Deleuze into conversation with Rawls and demonstrating his value for expanding our established liberal notion of pluralism is important. But such a 'reconciliatory' reading risks squeezing one or both of the thinkers into an uncomfortable box, and given the nature of Tampio's project, this tends to happen more with Deleuze than with Rawls. At certain points, Rawls and Deleuze are placed on opposite ends of a continuum, such that Rawls is presented as more conservative and conciliatory, Deleuze as more radical and combative, Rawls as supporting the philosopher as a judge who upholds the law, Deleuze as supporting the nomadic criminal who breaks the law (pp. 67-69), and so on. Establishing such differences of degree between Rawls's and Deleuze's thinking, however, overlooks somewhat the differences in kind between them. Regardless of how Rawls might view the difference between judge and criminal, for example, it is hard to see Deleuze distinguishing them in terms of upholding versus undermining law; rather, for Deleuze the judge is one who evaluates using fixed tables of transcendent values while the nomad/criminal evaluates in order to create new values: it is another kind of law rather than an absence of law. Other times, elisions take place seemingly to align Deleuze and Rawls. At one point Tampio holds that Deleuze considers liberal democracies to be among the possible political regimes that substitute love of freedom for affects and passions such as fear, hope, and security (p. 149), but the passage from What is Philosophy? that he only partially quotes speaks only of democracies, not of liberal democracies. Elsewhere, Tampio holds that Deleuze 
acknowledges that without the protection of established majority and minority identities, politics would degenerate into chaos, but the pages referenced in A Thousand Plateaus make a rather different point: that while the struggles of minorities on the level of rights are not unimportant, their significance is that they serve as indexes for struggles of another order. And at another point Tampio quotes a passage from A Thousand Plateaus about the different ways the field of immanence can be constructed, and extrapolates from it that 'we have a choice about how to lay out philosophical planes of immanence' (p. 134), but the passage in question never speaks in terms of choices that, presumably, would be made by a subject (perhaps along the lines that Rawls's hypothetical subject chooses in the original position).

The last example points to a way that Tampio defines several key Deleuzian terms in a way that orients them towards a Rawlsian kind of theorizing. He takes Deleuze's idea of conceptual persona, for example, to be 'a conception of the person' (p. 124) that is grounded 'on psychosocial types' (p. 127) in order to formulate a functional equivalence between Rawls's rational agent and Deleuze's $\mathrm{BwO}$; the $\mathrm{BwO}$, in turn, is presented as sharing 'certain structural features with a democratic citizen' (p. 25), as having 'a fairly stable identity as a person (subjectivity)', and as being a conceptual persona corresponding 'to the psychosocial type of the normal human being in any given society' (p. 128). All this sits rather awkwardly with statements from Deleuze that present conceptual personae as dramatizations of vectors of thought, that present the $\mathrm{BwO}$ not as an individual person or subject but as a pre-personal 'collectivity' on which the person is both constituted and deterritorialized (hence it is never $m y \mathrm{BwO}$; rather, the 'me' is placed on it), and that conceptual personae and psychosocial types are irreducible, as the latter trace the (static) structure of the social field while the former relate to movements affecting the Socius (see Deleuze and Guattari, 1994, pp. 67-70). But it seems to be a consequence of trying to portray Rawls and Deleuze as doing the same thing: presenting 'a mental portrait that reflects one's deepest interests and aspirations as well as the situation one finds oneself in the world' (p. 135), placing 'the conception of the person on a mental landscape' (p. 136), and then proposing and evaluating the experimental theories that emerge from these constructs.

The lessons Tampio offers to political liberals are still important ones, and if they come by way of pushing some of Deleuze's concepts into alien territory, this is certainly in keeping with the way Deleuze himself reads many others. Nonetheless, Tampio also presents a different relationship between Deleuze and mainstream liberal theory when he writes: 'if mainstream political science or theory describes the power relations between definable entities, Deleuzian political theory helps us perceive the virtual layer of politics that is real but not amenable to common sense or scientific representation' (p. 176). Here Deleuze is no longer pursuing a similar project to Rawls and differing only in degree of emphasis or perspective, but instead operating at a different level, exploring a constitutive micropolitical realm where considerations of subjects and reflective choices are inappropriate and inapplicable, and where different rules for engagement and analysis are needed. This micropolitics 
is premised on the idea that we must change ourselves before we change the institutional, coalitional or distributive politics that are the usual focus of liberal theory, and it involves aspects of selfhood, language, power, desire and their relation to macroscopic sociopolitical processes that Rawls (1985, p. 230) explicitly eschews when declaring that his own theory is 'political not metaphysical' and that it 'deliberately stays on the surface, philosophically speaking'. Pushing liberal Enlightenment thought in this direction is as crucial as pressing it to expand its notion of pluralism to encompass a wider array of identities and faiths. But the price it may exact is that the name 'liberalism' may no longer be suitable for this politics. Nor might 'Marxism' be, even if Deleuze considered himself a Marxist throughout his career, linking an analysis of capitalism to a form of (molecular) revolution. Regardless of the appropriate name, however, this politics involves the very same courage that Tampio's book articulates and develops so persuasively.

\title{
Notes
}

1 Deleuze in particular shows how Kant himself, in the Critique of Judgment, identifies an experience of the sublime in which the faculties break with common sense and become creative (p. 94).

2 Tampio draws these distinctions from Israel's (2001) seminal study, Radical Enlightenment: Philosophy and the Making of Modernity, 1650-1750.

\section{References}

Bronner, S. (2004) Reclaiming the Enlightenment: Toward a Politics of Radical Engagement. New York: Columbia University Press.

Deleuze, G. and Guattari, F. (1994) What Is Philosophy? Translated by H. Tomlinson and G. Burchell. New York: Columbia University Press.

Israel, J. (2001) Radical Enlightenment: Philosophy and the Making of Modernity, 1650-1750. New York: Oxford University Press.

Tampio, N. (2014) Entering Deleuze's political vision. Deleuze Studies 8(1): 1-22.

Rawls, J. (1985) Justice as fairness: Political not metaphysical. Philosophy and Public Affairs 14(3): 223-251.

\author{
Nathan Widder \\ Royal Holloway, University of London, Surrey, UK \\ n.e.widder@rhul.ac.uk
}

